\title{
KONSUMSI JANTUNG PISANG TERHADAP PENINGKATAN PRODUKSI ASI PADA IBU
}

\author{
Ratna Wulandari ${ }^{1}$, Riska Yanti Harahap ${ }^{2}$ \\ Akademi Kebidanan Paluta Husada \\ e-mail: ${ }^{1}$ wulan_surb@yahoo.com, ${ }^{2}$ yantiriska745@gmail.com
}

\begin{abstract}
Breastmilk (ASI) is the best food for babies because it is a perfect natural food, easily digested by babies and contains nutrients that are in accordance with the baby's needs for growth, immunity and preventing various diseases as well as for the baby's intelligence, safe and guaranteed cleanliness. Another benefit that is no less important than exclusive breastfeeding as mentioned above is that breast milk is highly nutritious, affordable and can protect babies from Sudden Infant Death Syndrome (Sudden Infant Death Syndrome). This research is a quasy experimental study to examine the causal relationship or to find the effect of an intervention on the population. This research was conducted in the working area of the Puskesmas Portibi on the grounds that the work area of the puskesmas used the Wilcoxon signed rank test to see the effect of before and after consuming banana blossomon the increase in the respondent's milk production. The results of this study indicate a p-value of $0.000(\alpha<0.05)$, which means that there is an effect of consuming banana blossoms on increasing breast milk production in mothers in the work area of Puskesmas Portibi, Padang Lawas Utara Regency in 2020.
\end{abstract}

Keywords: Banana Blossom; Breastmilk Production.

\begin{abstract}
ABSTRAK
Air Susu Ibu (ASI) adalah makanan terbaik untuk bayi karena merupakan makanan alamiah yang sempurna, mudah dicerna oleh bayi dan mengandung zat gizi yang sesuai dengan kebutuhan bayi untuk pertumbuhan, kekebalan dan mencegah berbagai penyakit serta untuk kecerdasan bayi, aman dan terjamin kebersihannya. Manfaat lain yang tidak kalah penting dari ASI eksklusif seperti yang telah disebutkan di atas karena ASI bergizi tinggi, terjangkau dan dapat melindungi bayi dari sindrom kematian bayi mendadak atau SIDS (Sudden Infant Death Syndrome). Penelitian ini adalah penelitian quasy experimen untuk menguji hubungan sebab akibat atau mencari pengaruh dari suatu intervensi terhadap populasi. Penelitian ini dilakukan di wilayah kerja Puskesmas Portibi dengan alasan diwilayah kerja puskesmas dengan uji wilcoxon signed rank test untuk melihat pengaruh sebelum dan sesudah mengkonsumsi jantung pisang terhadap peningkatan produksi ASIresponden. Hasil penelitian ini menunjukkan nilai $p$-value $0.000(\alpha<0.05)$ yang artinya ada pengaruh mengkonsumsi jantung pisang terhadap peningkatan produksi ASI pada ibu di wilayah kerja Puskesmas Portibi Kabupaten Padang lawas Utara Tahun 2020.
\end{abstract}

Kata kunci:Jantung Pisang; Produksi ASI.

\section{PENDAHULUAN}

\section{Latar Belakang}

Air susu ibu (ASI) adalah makanan terbaik untuk bayi karena merupakan makanan alamiah yang sempurna, mudah dicerna oleh bayi dan mengandung zat gizi yang sesuai dengan kebutuhan bayi untuk pertumbuhan, kekebalan dan mencegah berbagai penyakit serta untuk kecerdasan bayi, aman dan terjamin kebersihannya. Manfaat lain yang tidak kalah penting dari ASI eksklusif seperti yang telah disebutkan di atas karena ASI bergizi tinggi, terjangkau dan dapat melindungi bayi dari sindrom kematian bayi mendadak atau SIDS (Sudden Infant Death Syndrome). Namun, menciptakan pemberian ASI sejak hari per tama tidak selalu mudah karena banyak ibu menghadapi masalah dalam melakukannya. Kejadian yang sering terjadi pada hari pertama menyusui adalah sulitnya ASIkeluar. ${ }^{1}$

Cakupan pemberian ASI Eksklusif secara nasional di Indonesia berfluktuasi selama 3 tahun terakhir, cakupan pemberian ASI eksklusif pada bayi $0-5$ bulan turun dari 62,2\% tahun 2017 menjadi $56,2 \%$ pada tahun 2018. Menurunnya angka pemberian ASI eksklusif ini disebabkan oleh rendahnya pengetahuan para ibu mengenai manfaat ASI dan cara menyusui yang benar, Agar ibu berhasil dalam memberikan ASI secara eksklusif, maka ibu yang sedang menyusui bayinya harus mendapat tambahan makanan untuk menghindari kemunduran dalam pembuatan dan produksi ASI. Jika makanan ibu terus-menerus tidak memenuhi asupan gizi yang cukup, tentu kelenjar-kelenjar pembuat air susu dalam payudara ibu tidak akan bekerja dengan sempurna dan pada akhirnya akan berpengaruh terhadap produksi 
ASI. Ibu menyusui harus memperhatikan beberapa hal untuk meningkatkan kualitas dan jumlah volume ASI yang dimilikinya. Ada beberapa saran yang perlu diperhatikan para ibu yang sedang memberikan ASI pada bayi, yaitu: mengkonsumsi sayur-sayuran khususnya jantung pisang yang dapat meningkatkan volume ASI. ${ }^{2}$

\section{Tujuan Penelitian}

Tujuan penelitian ini adalah untuk menganalisis pengaruh konsumsi jantung pisang terhadap peningkatan produksi ASI di wilayah kerja Puskesmas Portibi Kabupaten Padang Lawas Utara.

Rendahnya pencapaian program pemberian ASI eksklusif pada bayi dipengaruhi oleh rendahnya pengetahuan ibu tentang peningkatan produksi dan kualitas ASI. Salah satu intervensi yang dapat dilakukan pada ibu menyusui adalah dengan mengkonsumsi jantung pisang dalam meningkatkan kualitas dan produksi ASI.

\section{Hipotesis (Opsional)}

Ada pengaruh konsumsi jantung pisang terhadap peningkatan produksi ASI pada Ibu Di Wilayah Kerja Puskesmas Portibi Kabupaten Padang Lawas Tahun 2020.

\section{METODE}

Penelitian ini adalah penelitian quasy experimen untuk menguji hubungan sebab akibat atau mencari pengaruh dari suatu intervensi terhadap populasi tanpa adanya randomisasi penetuan subjek penelitian. Rancangan peneltian yang digunakan adalah one group pre-post test designe yang dilakukan dengan memberikan perlakuan pada kelompok intervensi sebelum dan sesudah mengkonsumsi jantung pisang.

Peneliti melakukan pengumpulan data dengan menggunakan instrumen pengukuran volume ASI dan data skunder berupa catatan rekam medis responden.Analisa data yang digunakan dalam penelitian ini adalah uji wilcoxon signed rank test untuk melihat pengaruh sebelum dan sesudah mengkonsumsi jantung pisang terhadap peningkatan produksi ASI responden. Adapun alasan menggunakan uji ini adalah memiliki skala ukur ordinal dan untuk melihat perlakuan yang diberikan terhadap kelompok intervensi yang berpasangan yaitu pre-post test design. ${ }^{8}$

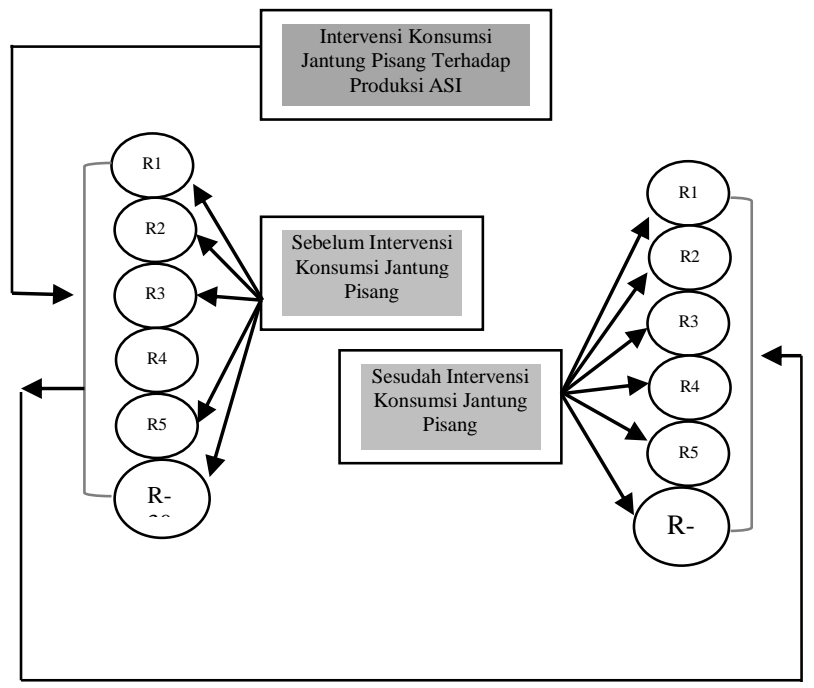

Gambar 1 Alur Kerja Penelitian

\section{HASIL}

Dalam penelitian ini yang bertindak sebagai variabel dependent adalah kejadian ibu nifas dengan peningkatan Produksi ASI, sedangkan variabel independent adalah jantung pisang. Instrument penelitian adalah lembar observasi peningkatan konsumsi jantung pisang produksi ASI sebelum dan sesudah mengkonsumsi jantung pisang di wilayah kerja Puskesmas Portibi Kabupaten Padang Lawas Utara Tahun 2020 diperoleh hasil sebagai berikut :

Tabel 1.

Rata-rata Produksi Asi Sebelum dan Sesudah Mengkonsumsi Jantung Pisang

\begin{tabular}{clcccc}
\hline No. & $\begin{array}{c}\text { Peningkatan } \\
\text { ASI }\end{array}$ & Mean & SD & SE & $\begin{array}{c}\text { Min- } \\
\text { Max }\end{array}$ \\
\hline 1. & $\begin{array}{l}\text { ASI Sebelum } \\
\text { Mengkonsumsi }\end{array}$ & 4,90 & 0,854 & 0,168 & $3-6$ \\
& Jantung Pisang & & & & \\
2. & $\begin{array}{l}\text { ASI Sesudah } \\
\text { Mengkonsumsi } \\
\text { Jantung Pisang }\end{array}$ & 7,37 & 0,765 & 0,146 & $3-8$ \\
& & & & \\
\end{tabular}

Berdasarkan tabel diatas dapat diketahui bahwa rata-rata ASI ibu sebelum pemberian jantung pisang pada ibu terhadap 30 orang ibu menyusui, dengan mean 4,90standar deviasi 0,854 standar eror 0,168 dan nilai min-max 3-6. Dari tabel diatas dapat diketahui bahwa rata-rata ASI ibu sesudah pemberian jantung pisang pada ibu terhadap 30 orang ibu menyusui, dengan mean 7,37standar deviasi 0,765 standar eror 0.146 dan nilai min-max 4-8. 
Tabel 2.

Pengaruh Konsumsi Jantung Pisang Dengan Peningkatan ASI $(\mathrm{N}=30)$

\begin{tabular}{cccccc}
\hline No. & Variabel & Mean & SD & T-Test & P-Value \\
\hline 1. & Pretest & 5,06 & 0,873 & - & \\
& & & & 7,100 & 0,000 \\
2. & Posttest & 7,22 & 1,166 & & \\
\hline
\end{tabular}

Berdasarkan tabel terlihat bahwa perbedaan hasil pengukuran rata-rata ASI ibu sebelum pemberian sayur jantung pisang pada ibu terhadap 30 orang ibu menyusui, dengan mean 5,06standar deviasi 0,873. Rata-rata ASI ibu sesudah pemberian jantung pisang pada ibu, dengan mean 7,22standar deviasi 1,166. Hasil uji statistik menggunakan tes-dependen didapat nilai p-value $0.000 \quad(\alpha<0.05)$ yang artinya ada pengaruh konsumsi jantung pisang dengan peningkatan ASI pada ibu.

\section{PEMBAHASAN}

\section{A. Rata-Rata Produksi ASI Ibu Sebelum Mengkonsumsi Jantung Pisang}

Rata-rata ASI ibu sebelum pemberian jantung pisang pada ibu terhadap 30 orang ibu menyusui, dengan mean 4,90 standar deviasi 0,854 standar eror 0,168 dan nilai min-max 3-6. Proses produksi, sekresi, dan pengeluaran ASI dinamakan laktasi. Secara teoritis banyak faktor yang berpengaruh terhadap kelanaran ASI, baik faktor ibu maupun factor luar ibu. Keberhasilan laktasi dipengaruhi oleh kondisi sebelum dan saat hamil. Kondisi sebelum hamil ditentukan oleh perkembangan payudara saat lahir dan saat pubertas. Pada saat kehamilan yaitu trimester II payudara mengalami pembesaran karena pertumbuhan akan difrensiasi dari lobuloalveolus dan sel epitel payudara. Pada saat pembesaran payudara ini hormon prolaktin dan laktogen plasenta aktif bekerja yang berperan dalam produksi ASI. Sekresi ASI diatur oleh hormon prolaktin dan oksitosin. Prolaktin menghasilkan ASI dalam alveolar dan bekerjanya prolaktin ini dipengaruhi oleh lama dan frekuensi pengisapan (suckling). Hormon oksitosin disekresi oleh kelenjar pituitary sebagai respon adanya suckling yang akan menstimulasi sel mioepitel untuk mengeluarkan ASI. Hal ini dikenal dengan milk ejection reflex atau let downreflex yaitu mengalirnya ASI dari simpanan alveoli ke lacteal sinuses sehingga dapat dihisap bayi melalui puting susu. Faktor lain yang berpengaruh adalah frekuensi penyusunan, berat lahir, umur kehamilan saat melahirkan, umur dan paritas, stres dan penyakit akut, kebiasaan merokok, konsumsi alkohol, pil kontrasepsi. ${ }^{9}$
Sebagian besar ibu nifas sebelum konsumsi jantung pisang produksi ASI nya termasuk tidak lancar. Hal ini bisa dipengaruhi berbagai faktor baik kondisi sebelum maupun setelah hamil. Kondisi sebelum hamil ditentukan oleh perkembangan payudara saat lahir dan saat pubertas. Pada saat hamil trimester II jika payudara tidak mengalami pembesaran karena pertumbuhan dan diferensiasi lobuloalveolus dan sel epitel payudara maka bisa menghambat produksi ASI. Selain faktor tersebut juga didukung oleh berbagai faktor lain terkait karakteristik responden. Berdasarkan hasil penelitian diketahui mayoritas responden berumur 20- 30 tahun. Umumnya pada usia ini masih cenderung kurang peduli terhadap berbagai hal yang dapat memperlancar produksi ASI, misalnya perawatan payudara sebelum persalinan, konsumsi makanan tertentu yang dapat memperlancar produksi ASI dan berbagai hal lain. Oleh karenanya secara umum cenderung tidak lancar. Menurut peneliti, peningkatan ASI dipengaruhi oleh asupan makanan yang dikonsumsi, serta kandungan gizi dalam makanan yang dikonsumsi oleh ibu, salah satunya adalah makanan yang banyak mengandung laktogagum, hasil pengukuran pada kelompok pretes adalah 3, 4, 5, 6 dan 7 pada pengukuran pertama tidak ada responden yang memiliki peningkatan ASI kurang baik.

\section{B. Rata-Rata Produksi ASI Ibu Setelah Pemberian Sayur Jantung Pisang}

Rata-rata ASI ibu sesudah pemberian sayur jantung pisangpada ibu terhadap 30 orang ibu menyusui, dengan mean 7,37 standar deviasi 0,765 standar eror 0.146 dan nilai min-max 3-8.

Secara teknis kelancaran ASI dipengaruhi oleh berbagai makanan, salah satunya adalah jantung pisang yang bermanfaat untuk meningkatkan produksi ASI ibu nifas. Jantung pisang mengandung laktogogum yaitu zat gizi yang dapat melancarkan produksi ASI. Hasil penelitian sebelumnya menunjukan intensitas rata-rata frekuensi ASI sebelum konsumsi jantung pisang adalah 5,7 kali. Setelah mengkonsumsi jatung pisang pengalami peningkatan 9,75 kali. Hasil analisis menunjukan ada pengaruh konsumsi jantung pisang terhadap peningkatan produksi ASI ( $\rho$ value $0,000<0,05$ maka H0 ditolak). ${ }^{10}$

Jika hampir seluruh responden sesudah pemberian jantung pisang produksi ASI nya termasuk lancar, maka hal ini disebabkan dengan mengonsumsi jantung pisang maka ibu mendapatkan laktogogum yaitu suatu zat gizi yang dapat meningkatkan dan dapat memperlancar produksi ASI terutama pada ibu yang mengalami masalah dalam produksi ASI. Hasil penelitian ini juga sesuai dengan penelitian wahyuni (2012) yang menunjukan intensitas rata-rata frekuensi ASI sebelum konsumsi jantung pisang adalah 5,7 kali dan setelah konsumsi jantung pisang mengalami peningkatan 9,75 kali. Hal ini juga tampak dari responden setelah mengkonsumsi jantung pisang 
maka tampak dari adanya rembesan ASI dari payudara ibu, payudara tidak terlihat tegang karena proses penyusuan lancar, dan hasil evaluasi 2 bulan menunjukan adanya peningkatan produksi ASI dan rata-rata bayi lebih dari $10 \mathrm{kali} / 24 \mathrm{jam}$. Hal ini dapat dijadikan sebagai indikator adanya peningkatan produksi ASI dari ibu menyusui pasca mengkonsumsi jantung pisang.

Menurut peneliti, Untuk memperlancar produksi ASI sejumlah usaha bisa dilakukan yaitu dengan mengkonsumsi sejumlah booster ASI seperti herbal (daun katuk, daun kelor, jantung pisang dan lainnya) Jantung pisang dipilih karena merupakan jenis tanaman yang mengandung laktagogummemiliki potensi dalam menstimulasi hormon oksitosin dan prolaktin sepertialkaloid, polifenol, steroid, flavonoid dan substansi lainnya paling efektif dalammeningkatkan dan memperlancar produksi ASI. Pada pengukuran ke dua dari 30 responden terdapat 8 responden yang tidak mengalami peningkatan ASI setelah konsumsi sayur jantung pisang, dan sisanya mengalami kenaikan hingga 3-6 skor

\section{Pengaruh Konsumsi Jantung Pisang Dengan Peningkatan Produksi ASI}

Berdasarkan tabel 2 terlihat bahwa perbedaan hasil pengukuran rata-rata ASI ibu sebelum pemberian sayur jantung pisangpada ibu terhadap 30 orang ibu menyusui, dengan mean 5,06 standar deviasi 0,873. Rata-rata ASI ibu sesudah pemberian sayur jantung pisangpada ibu, dengan mean 7,22standar deviasi 1,166. Hasil uji statistik menggunakan tes-dependen didapat nilai $p$-value $0.000 \quad(\alpha<0.05)$ yang artinya terdapat pengaruh konsumsi sayur jantung pisang dengan peningkatan ASI pada ibu.

Salah satu makanan olahan tradisional dari tanaman pisang adalah bagian jantungnya.Karena hampir seluruh wilayah tanah air mengenal pohon pisang.Begitupun di provinsi lampung, jantung pisang juga diolah menjadi makanan yang dapat dinikamati sehari-hari. Jantung pisang ini diolah dengan berbagai macam cara, menyesuaikan menu yang disandingkan dengan sayur jantung pisang ini. Dapat dibuat santan, tumis, atau sekedar lalapan biasa. Jantung pisang merupakan jenis tanaman yang mengandung laktagogum memiliki potensi dalam menstimulasi hormon oksitosin dan prolaktin seperti alkaloid, polifenol, steroid, flavonoid dan substansi lainnya paling efektif dalam meningkatkan dan memperlancar produksi ASI. ${ }^{11}$

Berdasarkan analisis data diketahui bahwa, peningkatan ASI dipengaruhi oleh makanan yang mengandung gizi, dan mengandung senyawa kimia yang dapat merangsang produksi ASI yaitu senyawa laktogagum. Pada penelitian ini 30 responden mengalami peningkatan yang signifikan yaitu keseluruhan pada skor 8, hal ini dipengaruhi oleh usia responden yang masuk dalam kategori produktif yaitu 20-35 tahun, serta pekerjaan adalah IRT dan wiraswasta, sehingga ibu tidak mengalami kelelahan dan kesibukan bekerja. Sedangkan 13 responden mengalami peningkatan peningkatan ASI namun tidak signifikan, yaitu berada pada skor 6-7, hal ini dapat disebabkan oleh kurangnya asupan makanan yang dikonsumsi oleh responden, anatomi dan fisiologis bentuk payudara ibu, serta penggunaan KB.

\section{KESIMPULAN}

Berdasarkan hasil penelitian dapat disimpulkan bahwa ibu menyusui di Wilayah Kerja Puskesmas Portibi Kabupaten Padang Lawas Utara Tahun 2020, seluruh responden setelah mengkonsumsi jantung pisang produksi ASI nya mengalami peningkatan yang signifikan. Hal ini menunjukkan bahwa ada pengaruh konsumsi jantung pisang terhadap peningkatan produksi ASI pada ibu menyusui dengan nilai P-value0.000 $(\alpha<0.05)$.

\section{DAFTAR PUSTAKA}

1. Ely Tjahjani, Pengaruh Konsumsi Jantung Pisang Terhadap Kelancaran ASI Pada Ibu Nifas. Surabaya. 2014.

2. Roesli Utami, ASI Esklusif. PT Trubus Agri Widia:Jakarta.2018.

3. Arifin M.S, Jantung Pisang Sebagai Laktogogum.Di akses http://bp3kpkerinci.com. 2020.

4. Ratna, L.G. Jantung Pisang untuk Menambah ASI. Buletin Penelitian Sistem Kesehatan - Vol. 15 No. Tahun 2012.

5. Murtiana, T, Pengaruh Konsumsi Daun Katuk dengan Peningkatan Produksi ASI pada Ibu Menyusui di Wilayah Puskesmas Sawah Lebar Kota Bengkulu Tahun 2011.[Skripsi] Jurusan Kebidanan, Politeknik Kesehatan Bengkulu, Bengkulu. 2011.

6. Rilyani, Konsumsi Sayur Jantung Pisang Terhadap Peningkatan Produksi ASI Pada Ibu Masa Nifas. Holistik jurnal Kesehatan Vol.13 2019.

7. Notoatmodjo, Pendidikan Kesehatan dan Ilmu Perilaku. Rineka Cipta: Jakarta.2017.

8. Murti Bhisma, Desain dan Ukuran Sampel Untuk Penelitian Kuantitatif dan Kualitatif di Bidang Kesehatan. Gadjah Mada University Press:Yogyakarta. 2016.

9. Judarwanto, Asuhan Kebidanan Nifas DanMenyusui. Yogyakarta: Pustaka Belajar. 2013.

10. Wahyuni, E. Pengaruh Konsumsi Jantung 
Pisang Batu Terhadap Peningkatan Produksi ASI Di Wilayah Puskesmas Srikuncoro, Kecamatan Pondok Kelapa Bengkulu Tengah.[Skripsi] 2012.

11. Harismayanti, Pengaruh konsumsi jantung pisang terhadap peningkatan produksi asi pada ibu masa nifas. In prosiding seminar nasional 2018 "peran dan tanggung jawab tenaga kesehatan dalam mendukung program kesehatan nasional". 2019 